\title{
The Effects of Brand Image and Brand Identification on Brand Love and Purchase Decision Making: The Role of WOM
}

\author{
Methaq Ahmed Sallam ${ }^{1}$ \\ ${ }^{1}$ College of Administrative Sciences, Najran University, Najran, Saudi Arabia \\ Correspondence: Methaq Ahmed Sallam, College of Administrative Sciences, Najran University, P.O. box 1988, \\ 11001 Najran, Saudi Arabia. Tel: 966-556-573-2028. E-mail: methaq68@hotmail.com or methaq68@yahoo.com
}

Received: July 2, 2014

Accepted: August 8, 2014

Online Published: September 25, 2014

doi:10.5539/ibr.v7n10p187

URL: http://dx.doi.org/10.5539/ibr.v7n10p187

\begin{abstract}
When the customers focus on the positive aspects of a company, and they love its brand, they usually express about that by using the positive words of mouth communication, and this lead them to make purchase decision toward the products and services of the company. Brand love is a recent marketing construct, which has been shown to influence important marketing variables such as word-of-mouth and purchase decision making. This study aims to explore the variables effects, for example, (brand image and brand identification) on brand love and to illustrate the impact of brand love on purchase decision making when word of mouth is mediating. This is a theoretical study tries to develop a conceptual framework. Furthermore, this framework shows that brand image and brand identification are the antecedents of the study, brand love is the independent variable, WOM is the mediating variable and purchase decision making is the dependent variable of this study.
\end{abstract}

Keywords: brand image, brand identification, WOM and purchase decision making

\section{Introduction}

Lo Chung (2012) Mentioned that word of mouth deals with the process of transferring of information from one person to the other through oral communication. The concept of word of mouth has become an important term in the marketing activities conducted by various organizations. Interpersonal communication or the word of mouth has gained importance in the decision making of the consumers. Word of mouth is gaining importance among the societal changes observed in the environment and has become one of the most important and effective communication channel. Carroll and Ahuvia (2006) mentioned that there are few antecedent of brand love e.g. (self-expressive Brands, hedonic product category and brand identification). Brand image and brand identification play an important role in building the costumer's brand love, which is lead to form his/her positive word of mouth and lead the costumer to make purchase decision. Many previous studies used brand image and brand identification as antecedents of brand love, e.g. studies of (Bergkvist et al., 2009; Ismail et al., 2012). Costumer often makes his/her purchase decision according to positive or negative word of mouth and the level of brand love. Brand love is a recent marketing construct that, so far, has been the object of limited attention but seems to attract a steadily growing interest among academics as well as practitioners (Bergkvist et al., 2009). The study try to explore the effect of an antecedents e.g. (brand image and brand identification) on independent variable which is called brand love, in addition, the study will try to illustrate the impact of brand love on dependent variable which is namely purchase decision making when the word of mouth is mediator.

\section{Problem Statement}

Although many studies have been conducted on this issue, but there are still gaps which are needed to be filled in the literature. Studies conducted by previous researchers only focused on certain aspects of purchase decision making process, and the variables used in those studies were segmented in nature. In other words, the model proposed in this study is an integrative one came from three separate models found in the related area of literature, For example, study of (Lo Chung, 2012) explored the relationship between word of mouth and consumer's purchase decision making, study of (Ismail et al., 2012) illustrated the effect of brand love on consumer's word of mouth, and study of (Bergkvist et al., 2009) explored the relationship between brand image and brand love, while the study of (Ismail et al., 2012) explored the effect of brand identification on brand love. This means, that three main models of this study were segmented in three different studies, and each one was separated alone, and this study tries to integrate them in one conceptual framework, and this is the contribution of this study. 


\section{Literature Review}

For businesses that are offering products and services to the public, the customers are considered as one of the most important factors to be attended very carefully, since their wants and desires would have significant impacts on the way the businesses are run. Brand image, brand identification, brand love, as consequence of consumer's word of mouth and his/her purchase decision making are the main issues in this study which have a strong relation with the retention of customer as a key success factor in today's business world. These issues are discussed in details to allay concepts of these concerns here.

\subsection{Brand Image}

Brand image has been recognized as an important concept in marketing and consumer behavior research (Hee, 2009). The customer deals every day with different types of products and services, so, brand image that is primarily responsible for brand differentiation (Morgan, 2004). The companies compete to give good idea about their products and services to build a positive image about their brand in costumer's mind. So, good perception of product and service quality would drive the costumer to form a positive brand image, (Tan et al., 2012).

There is stream of literature that regards brand image as being directly related to the product category within which the brand is marketed (Martinez et al., 2004). Brand management scholars (e.g. Aaker, 1996; Kapferer, 1997) have argued that brand image is an essential part of powerful brands which enable brands to differentiate their products from their competitors. Brand image is made up of brand association, it is a set of perceptions about a brand as reflected by the brand associations held in the consumers' memory (Koubaa, 2008). Aaker (1991) defines brand associations as "the category of brand's assets and liabilities that include anything 'linked' in memory to a brand." Associations are informational nodes linked to the brand node in memory that contains the meaning of the brand for consumers (Keller et al., 1998, cited in Koubaa, 2008, p. 141). Keller (1993) goes on to explain that there are three important aspects of image: favorability, strength and uniqueness of brand associations. Moreover, the associations may be formed in one of the following categories: attributes of the product, benefits achieved from the product or attitudes towards the brand. The aim of every firm is to create favorable and positive associations about the brand which results in a positive image of the brand (Keller, 1993). Brand image is defined by Keller (1993, p. 3 ) as "the perceptions about a brand as reflected by the brand associations held in consumer memory". In other words brand image is what comes to the mind of the consumer when a brand name is mentioned. Basically, brand image describes the consumer's thoughts and feelings towards the brand (Roy \& Banerjee, 2007). Dobni and Zinkhan (1990) argued that the product image is the result of the interaction between the receiver and the product stimuli. Factors contributing to the development of brand image are: product attributes, the firm, the marketing mix, the individual perceptions of the brand, personal values, experience, type of brand users and context variables. Sources of image formation could be either through direct experience with the brand or brand communication (Dobni \& Zinkhan, 1990).

\subsection{Brand Identification}

Kuenzel et al., (2010) mentioned that the concept of brand identification is built on social identity theory, which has been employed widely in other disciplines. Identification based on social identity theory is in essence a perception of oneness with a group of persons. Brands possess deep meaning (Albert et al., 2013) and serve to build consumers' self-concept or identities. Brewer (1991) Informed that brand identification has been emphasized that identification fulfils the need for social identity and self - identification. Using the identification concept in a brand-customer context can be justified in terms of the social identity theory itself, where identification with an organization can also happen without a need to interact or have formal ties with an organization. Consumers with stronger brand identification are more prone to engage in pro-brand activities, such as supporting the company goals, protecting its reputation, supporting its products and brand loyalty (Bhattacharya \& Sen, 2003).

Brand identification is defined as 'the extent to which the consumer sees his or her own self-image as overlapping the brand's image (e.g. Sternberg et al., 1987; Bagozzi et al., 2006). Brand identification is also known as self-image congruence Sirgy M. J. et al., (1997) and self-connection. Although a number of previous studies (e.g. Algesheimer et al., 2005; Brown et al., 2005) have investigated the role of brand identification, none has investigated the relationship between brand identification and brand love. Bergkvist et al., (2009) informed that brand identification influences consumer's brand love, and they considered that brand identification as antecedents of brand love. Bergkvist et al., (2009) cited from (Ahuvia et al., 2006) that loved objects are central to people's identity. The informants in his study use objects they love to boost their identity and reconcile conflicting identities. Although Ahuvia does not explicitly discuss causality or causal order, his study suggests that a consumer is more likely to love a brand, the stronger, he or she identifies with. For example, Ahuvia reports how one of his informants requires a 'deep connection with what she sees as her desired identity as a culturally sophisticated 
bohemian' for her to love a product.

\subsection{Brand Love}

Since it was introduced by Shimp and Madden (1988), brand love has been a topic of great interest for brand managers. Customers can view a brand as an individual, so they can love a brand as they love a person (Ranjbarian et al., 2013). On the basis of Sternberg's (1986) tripartite conceptualization of interpersonal love, Shimp and Madden (1988) conceptualized consumer-brand relationship along three dimensions: liking, yearning and decision/commitment, which correspond to Sternberg's (1986) intimacy, passion and decision/commitment components of inter-personal love. Liking and yearning represent the feelings of intimacy with and passion for a brand, respectively. Similarly, on a cognitive level, decision refers to the individuals recognition of the liking and yearning for the brand in the short-term; whereas commitment is reflected in purchasing the same brand repeatedly over time.

Today companies have recognized that feeling of love toward a brand is a vital factor in establishing a good relationship with a customer, those brands which can make customers love their brands are more successful in gaining sustainable advantage and beating their competitors (Roberts, 2006). Marketing researchers have investigated the concept of brand love (Ahuvia, 2005; Fournier, 1998). Fournier (1998) answers the question of whether consumers can experience a feeling of love toward a brand, she established that such a feeling may exist and consumers may develop strong relationships with brands. Carroll and Ahuvia (2006) have stated that brand love is a blend of emotion and passion of an individual for a brand, in addition, they defined love for a brand as "the degree of passionate emotional attachment that a person has for a particular trade name." Consumers' love includes the following characteristics: "(1) passion for a brand, (2) brand attachment, (3) positive evaluation of the brand, (4) positive emotions in response to the brand, and (5) declarations of love toward the brand" (Albert et al., 2008).

Ahuvia et al. (2005) defined brand love as the degree of passionate emotional attachment a satisfied consumer has for a particular trade name. Bergkvist et al. (2009) mentioned that brand love and interpersonal love differ in that brand love is unidirectional, whereas interpersonal love is bi-directional 2 and that consumers are not expected to yearn for sexual intimacy with brands, a feeling generally associated with passionate interpersonal love. Moreover, love is generally regarded as qualitatively different from liking, that is, love is not extreme liking but rather a construct that is different from, but related to, liking (Sternberg, 1987).

Bergkvist et al. (2009) informed that brand love is important in a marketing context because it is positively related to brand loyalty and WOM.

\subsection{Word of Mouth}

Word-of-mouth means the measure of consumers' major informal communication. In early times, word- of-mouth meant at least two consumers, without commercial intention, communicating face-to-face regarding brands, products, or services. Communication is critical in customers' consumption and the process is called word-of-mouth (Ting \& Chen, 2005). Word-of-mouth (WOM) communication usually invites thoughts on others. Some people engage in WOM communication to seek other people's opinions on products or companies. Other people first consider the characteristics of potential WOM message receivers and then deliver WOM messages to the relevant receiver (Allsop, Bassett \& Hoskins, 2007)

Word of mouth is gaining importance among the societal changes observed in the environment and has become one of the most important and effective communication channel. Harrison-Walker (2001) defined WOM as "informal, person-to-person communication between a perceived non-commercial communicator and a receiver regarding a brand, a product, an organization or a service. The basic idea behind WOM is that information about products, services, stores, companies and so on can spread from one consumer to another. In its broadest sense, WOM communication includes any information about a target object (e.g. company, brand) transferred from one individual to another either in person or via some communication medium (Brown et al., 2005). WOM is described as the process that allows consumers to share information and opinions that direct buyers toward and away from specific products, brands and services (Hawkins et al., 2004). There is recent focus on WOM in the literature on relationship marketing as a potential response that can emerge from efforts directed at forming relationships with consumers (e.g. Verhoef et al., 2002).

Lo (2012) mentioned that word of mouth has been an age old concept where a person shares his view with another person. The views of the person can be related to a product or the service he have received. The studies in consumer behavior suggest that words of mouth have a strong influence on the psychology of the person. The influence of word of mouth can have both positive and negative aspects. Relating word of mouth to the consumer behavior, it can be interpreted that the positive word of mouth increases the likelihood of the consumers in opting 
for the product, whereas the negative word of mouth does the reverse. The overall effect of the word of mouth is dependent on two factors. The total number of people being exposed to positive word of mouth or negative word of mouth helps in judging the final influence.

\subsection{Purchase Decision Making}

Decision making is painful (Pfister, 2003). It requires effortful processing of available information to reach a suitable judgment. Thus, consumers may rely on inferences to make a choice. Huber and McCann (1982) have shown that inferences can affect how people evaluate products. Family members play an important role in the purchase decision process, and this process is taken collectively or individually. The importance of the family as a unit of analysis in consumer purchase decision-making is well established (Xia et al., 2006). The family as a critical purchase and consumption decision-making unit has attracted the attention of several authors (Commuri \& Gentry, 2000; Levy \& Lee, 2004; Ndubisi \& Koo, 2006). There are many previous studies that illustrated the purchase decision making from the viewpoint of the family e.g. (Xia et al., 2006), while the others focused on the subject from the viewpoint of the couple (Frikha, 2010). But the issue of purchase decision-making remains renewed because it happens on daily, in all the time and everywhere. Although children will have an influence in certain unique product categories (e.g. breakfast cereals), their impact on day-to-day family decision making is limited (Spiro, 1983). Therefore, the fundamental question of who makes what purchase decisions in the family generally resides with the husband and the wife (Howard, 1989). Who makes the decision to buy it in the family is a matter of difference depends on the consumer culture and this is different from the country to another (Tony et al., 1997). So, we can define purchase decision making as process by which (1) consumers identify their needs, (2) collect information, (3) evaluate alternatives, and (4) make the purchase decision. These actions are determined by psychological and economical factors, and are influenced by environmental factors such as cultural, group, and social values (Xia et al., 2006).

\subsection{The Relationship between Brand Image, Brand Identification and Brand Love}

Previous studies considered brand image and brand identification as antecedents to brand love e.g. (Bergkvist et al., 2009; Ismail et al., 2012). In terms of brand image and brand love, there is strong relationship between brand image and brand love, for example, (Aaker, 1997; Fournier, 1998; Ismail et al., 2012) found positive and significant effect of brand image on brand love. In terms of brand identification and brand love, also, previous studies found there is strong relationship between brand identification and brand love, for example, (Bergkvist et al., 2009; Kressman et al., 2006; Albert et al., 2013) found that brand identification had positive effect on brand love.

According to what mentioned above, the study hypothesizes that both brand image and brand identification have positive effect on brand love.

\subsection{The Relationship between Brand Love and WOM}

If consumers feel they love the brand that in turn may translate into a desire of the recommend it to friends and relatives. So, many people use their word of mouth to inform others about products or services positively or negatively. With respect to this topic, many previous studies found there is strong relationship between brand love and costumer's word of mouth, e.g. (Ahuvia et al., 2006; Elaine et al., 2014; Ismail et al., 2012; Mark et al., 2014) found that brand love is positively related to consumer's word of mouth. According to what mentioned above, the study hypothesizes that brand love has strong positive effect on consumer's word of mouth.

\subsection{The Relationship between WOM and Purchase Decision Making}

It has been accepted in the present market scenario that word of mouth has become a powerful strategy for the marketing professionals. It has been found that the word of mouth has a significant role to play in influencing the customers to purchase a product; it has been found that often organizations induce their views in the word of mouth, (Villanueva et al., 2008). Lo (2012) found that word of mouth has a huge significance in influencing the purchase making decision of a consumer. Wang, X., (2011) informed that word of mouth has strong effect on consumer purchase decision making. In addition, (Trusov et al., 2009) referred that word of mouth has positive effect on consumer's purchase decision making, in addition, Dongsuk, (2007) found that word of mouth had positive effect on consumer's purchase decision. Even studies that have looked at the impact of e-WOM on customer purchase decision making and which is consider very closed to our study e.g. (Christodoulides et al., 2010; Huang et al., 2009; O'Reilly et al., 2011) explored that e-WOM has positive effect on costumer purchase decision making. According to what mentioned above, the study hypothesizes that: costumer' word of mouth has positive impact on his/her purchase decision making.

\section{The Proposed Conceptual Framework}

The conceptual framework below is proposed to ensure that brand image and brand identification are as 
antecedents of the independent variable which is namely brand love e.g. (Bergkvist, et al., 2009; Ismail, et al., 2012). Brand love impacts on dependent variable which is called consumer's purchase decision making when WOM is mediating.

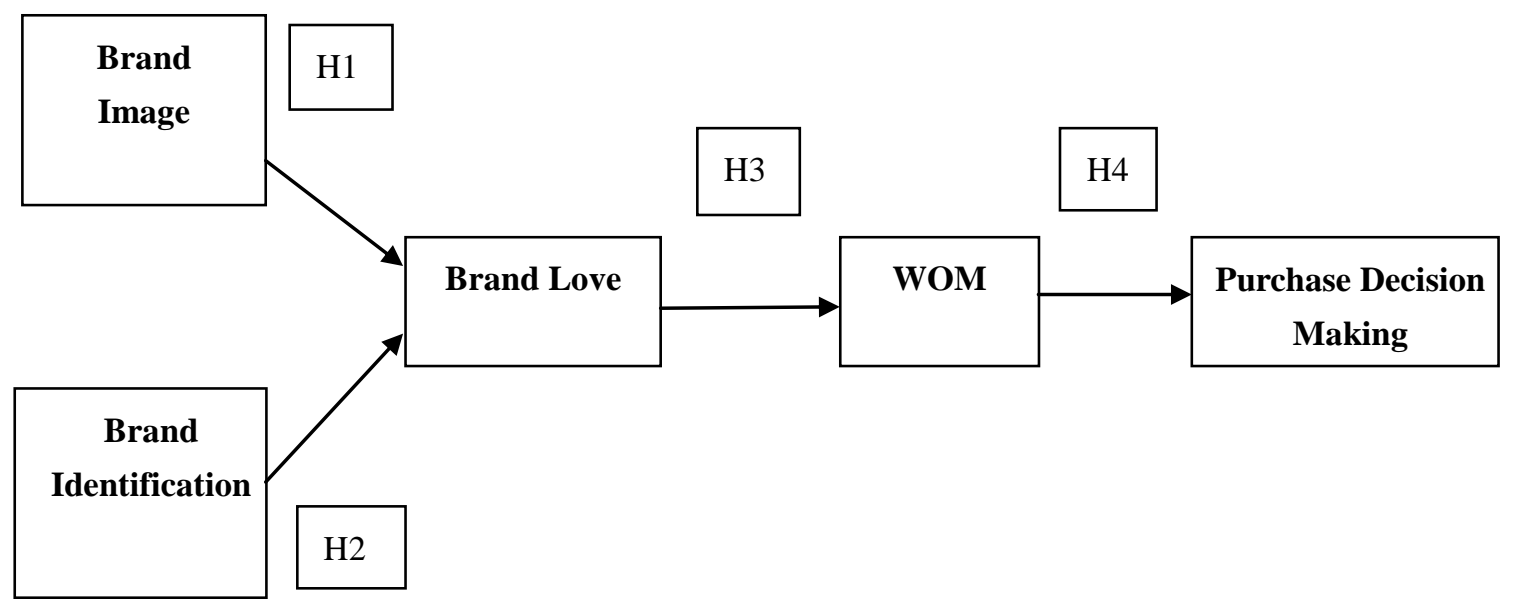

Figure 1. Conceptual framework of the study

\section{Conclusion}

This study aims to determine a conceptual framework, create consumer's purchase decision making by build consumer's brand love and to illustrate the role of mediating variable which is namely consumer's word of mouth. If the study were applied in practice in the future by one of the researchers, the results will inform the company mangers how to use the antecedents variables e.g. (brand image and brand identification) well, to explore their effects on brand love, and to illustrate which one has the strong effect on brand love. In addition, the study will give the researchers idea about the mediating role of WOM between brand love and consumer's purchase decision making whether partial or full mediating.

\section{References}

Aaker, D. A. (1991). Managing Brand Equity: Capitalizing on the Value of a Brand Name. New York, NY: The Free Press.

Aaker, D. A. (1996). Building Strong Brands. New York, NY: The Free Press.

Aaker, J. L. (1997). Dimensions of brand personality. Journal of Marketing, 34(3), 47-56.

Albert, N., \& Merunka, D. (2013). The role of brand love in consumer-brand relationships. Journal of Consumer Marketing, 30(3), 258-266. http://dx.doi.org/10.1108/07363761311328928

Albert, N., Merunka, D., \& Vallette-Florence, P. (2008). When consumers love their brands: exploring the concept and its dimensions. Journal of Business Research, 61(10), 1062-75. http://dx.doi.org/10.1016/j.jbusres.2007.09.014

Allsop, D. T., Bassett, B. R., \& Hoskins, J. A. (2007). Word-of-mouth re-search: Principles and applications. Journal of Advertising Research, 398-411. http://dx.doi.org/10.2501/S0021849907070419

Bergkvist, L., \& Larsen, T. B. (2010). Two studies of consequences and actionable antecedents of brand love. Journal of Brand Management, 17(7), 504-518. http://dx.doi.org/10.1057/bm.2010.6

Brewer, M. B. (1991). The social self: On being the same and different at the same time. Personality and Social Psychology Bulletin, 17, 475-482. http://dx.doi.org/10.1177/0146167291175001

Brown, T. J., Barry, T. E., Dacin, P. A., \& Gunst, R. F. (2005). Spreading the word: antecedents of consumers' positive word-of-mouth intentions and behaviours in a retailing context. Journal of Academy of Marketing Science, 33(2), 123-38. http://dx.doi.org/10.1177/0092070304268417

Carroll, B. A., \& Ahuvia, A. C. (2006). Some antecedents and outcomes of brand love. Marketing Letters, 17(2), 79-89. http://dx.doi.org/10.1007/s11002-006-4219-2

Christodoulides, G., \& Argyriou, E. (2010). Cross-national differences in e-WOM influence. European Journal of 
Marketing, 46(11/12), 2012.

Commuri, S., \& Gentry, J. W. (2000). Opportunities for family research in marketing. Academy of Marketing Science. Retrieved from http://www.amsreview.org/articles/commuri08-2000.pdf

Dongsuk, J. (2007). Effects of word-of-mouth communication on purchasing decisions in restaurants: A path analytic study. ProQuest Dissertations and Theses, 2007, ProQuest.

Elaine, W., Isable, B., \& Leslie D. (2014). Consumer engagement with self-expressive brands: brand love and WOM outcomes. The Journal of Product and Brand Management, 23(1), 33-42. http://dx.doi.org/10.1108/JPBM-06-2013-0326

Fournier, S. (1998). Consumers and their brands: developing relationship theory in consumer research. Journal of Consumer Research, 24(4), 343-73. http://dx.doi.org/10.1086/209515

Frikha, A. (2010). Conflict in purchase decision making within couples. Journal of Islamic Marketing, 1(3). http://dx.doi.org/10.1108/17590831011082419

Harrison-Walker, L. J. (2001). E-complaining: a content analysis of an internet complaint forums. Journal of Service Marketing, 15(5), 397-412. http://dx.doi.org/10.1108/EUM0000000005657

Hawkins, D. I., Best, R., \& Coney, K. A. (2004). Consumer Behavior: Building Marketing Strategy (9th ed.). Boston, MA: McGraw-Hill.

Hee, P. S. (2009). The antecedents and consequences of brand image: Based on Keller's customer-based brand equity. The Ohio State University, ProQuest, UMI Dissertations Publishing.

Howard, J. A. (1989). Consumer Behavior in Marketing Strategy. Englewood Cliffs, NJ: Prentice-Hall.

Huang, M., Cai, F., Tsang, A., \& Zhou, N. (2009). Making your online voice loud: the critical role of WOM information. European Journal of Marketing, 45(7/8), 201.

Huber, J., \& McCann, J. (1982). The impact of inferential beliefs on product evaluations. Journal of Marketing Research, 19, 324-33. http://dx.doi.org/10.2307/3151566

Ismail, A. R., \& Spinelli, G. (2012). Effects of brand love, personality and image on word of mouth: The case of fashion brands among young consumers. Management, 16(4).

Keller, K. L. (1993). Conceptualizing, measuring, and managing customer-based brand equity. Journal of Marketing, 57(1), 1-22. http://dx.doi.org/10.2307/1252054

Koubaa, Y. (2008). Country of origin, brand image perception, and brand image structure. COO and brand image. Asia Pacific Journal of Marketing and Logistics, 20(2). http://dx.doi.org/10.1108/13555850810864524

Kressman, F., Sirgy, M. J., Herrman, A., Huber, F., Huber, S., \& Lee, D. J. (2006). Direct and indirect effects of self-image congruence on brand loyalty. Journal of Business Research, 59(9), 955-964. http://dx.doi.org/10.1016/j.jbusres.2006.06.001

Kuenzel, S., \& Halliday, S. S. (2010). The chain of effects from reputation and brand personality congruence to brand loyalty: The role of brand identification. Journal of Targeting, Measurement and Analysis for Marketing, 18(3/4), 167-176. http://dx.doi.org/10.1057/jt.2010.15

Levy, D. S., \& Lee, K. C. (2004). The influence of family members on housing purchase and decisions. Journal of Property Investment \& Finance, 22(4/5), 320-338. http://dx.doi.org/10.1108/14635780410550885

Lo, S. C. (2012). Consumer decision: The Effect of Word of Mouth. The International Journal of Organizational Innovation, 4(3).

Mark, F., Michele, B., Filho, C., \& Souki, G. C. (2014). The effect of product category on consumer brand relationships. Journal of Product and Brand Management, 23(2), 78-89. http://dx.doi.org/10.1108/JPBM-05-2013-0310

Martinez, E., \& Chernaton, L. (2004). The effect of brand extension strategies upon brand image. The Journal of Consumer Marketing, 21(1), 39. http://dx.doi.org/10.1108/07363760410513950

Morgan, F. N. (2004). Brand Image Formation and Updating Across Multiple-Episode Experiences Within Service Networks. A Dissertation Presented in Partial Fulfillment of the Requirements for the Degree Doctor of Philosophy, Arizona State University.

Ndubisi, N. O., \& Koo, J. (2006). Family structure and joint purchase decisions: two products analysis. Management Research News, 29(1/2), 53-64. http://dx.doi.org/10.1108/01409170610645448 
O'Reilly, K., \& Marx, S. (2011). How young, technical consumers assess online WOM credibility. Qualitative Market Research: An International Journal, 14(4), 330-359. http://dx.doi.org/10.1108/13522751111163191

Pfister, R. H. (2003). Decision making is painful- we knew it all along. Journal of Behavioral Decision Making, 16(1), 73. http://dx.doi.org/10.1002/bdm.424

Ranjbarian, B., Kazemi, A., \& Borandeg, F. (2013). Analyzing the Antecedents and Consequences of Brand Love with a Case Study on Apple Cell phone Users. International Journal of Academic Research in Business and Social Sciences November, 3(11). http://dx.doi.org/10.6007/IJARBSS/v3-i11/341

Roberts, K. (2006). Love marks: The Future Beyond Brands. New York: Power House Books.

Roy, D., \& Banerjee, S. (2007). CARE-ing strategy for integration of brand identity with brand image. International Journal of Commerce and Management, 17(1/2), 140-8. http://dx.doi.org/10.1108/10569210710776512

Sen, S., Bhattacharya, C. B., \& Korschun, D. (2006). The Role of Corporate Social Responsibility in Strengthening Multiple Stakeholder Relationships: A Field Experiment. Journal of the Academy of Marketing Science, 34(2), 158-166. http://dx.doi.org/10.1177/0092070305284978

Shimp, T. A., \& Madden, T. J. (1988). Consumer-object relations: a conceptual framework based analogously on Sternberg's triangular theory of love. Advances in Consumer Research, 15(1), 163-168.

Spiro, R. L. (1983). Persuasion in family decision making. Journal of Consumer Research, 9, 393-402. http://dx.doi.org/10.1086/208933

Sternberg, R. J. (1986). A triangular theory of love. Psychological Review, 93(2), 119-135. http://dx.doi.org/10.1037/0033-295X.93.2.119

Sternberg, R. J. (1987). Liking versus loving: Acomparative evaluation of theories. Psychological Bulletin, 102(3), 331-345. http://dx.doi.org/10.1037/0033-2909.102.3.331

Tan, T. M., Liew, T. W., William, L. S., Michelle, O. B., \& Tan, S. M. (2012). Consumer-based Brand Equity in the Service Shop. International Journal of Marketing Studies, 4(4).

Ting, I. H., \& Chen, M. Y. (2005). Data Mining. Taichung City, Cang Hai Books.

Tony, H., Micheal, L., \& Tim, H. (1997). Japanese couples' marital roles in stages of product purchase decision making. International Marketing Review, 14(1), 39-58. http://dx.doi.org/10.1108/02651339710159206

Trusov, M., Bucklin, R. E., \& Pawls, K. (2009). Effects of Word-of-Mouth versus Traditional Marketing: Findings from an Internet Social Networking Site. Journal of Marketing, 73, 90-102. http://dx.doi.org/10.1509/jmkg.73.5.90

Verhoef, P. C., Franses, P., \& Hoekstra, J. C. (2002). The effect of relational constructs on customer referrals and number of services purchased from a multiservice provider: does age of relationship matter? Journal of Academy of Marketing Science, 30(3), 202-12. http://dx.doi.org/10.1177/0092070302303002

Villanueva, J., Yoo, S., \& Hanssens, D. M. (2008). The Impact of Marketing-Induced Versus Word-of-Mouth Customer Acquisition on Customer Equity Growth. Journal of Marketing Research, 45(1), 48-59. http://dx.doi.org/10.1509/jmkr.45.1.48

Wang, X. (2011). The effect of inconsistent word of mouth during service encounter. Journal of Services Marketing, 25(4), 252-259. http://dx.doi.org/10.1108/08876041111143087

Xia, Y., Ahmed, U., \& Ghingold, M. (2006). Spousal influence in Singaporean family purchase decision-making process A cross-cultural comparison. Asia Pacific Journal of Marketing and Logistics, 18(3), 201-222. http://dx.doi.org/10.1108/13555850610675661

\section{Copyrights}

Copyright for this article is retained by the author(s), with first publication rights granted to the journal.

This is an open-access article distributed under the terms and conditions of the Creative Commons Attribution license (http://creativecommons.org/licenses/by/3.0/). 